\title{
In the eye of a hurricane there is quiet, for just a moment,
}

\author{
Vanessa Thomas \\ Department of Computer \\ Science \\ Aarhus University \\ vanessa@cs.au.dk \\ Ding Wang \\ Department of Computer \\ Science \\ University of Bristol \\ ding.wang@bristol.ac.uk \\ Andy Darby \\ HighWire Centre for Doctoral \\ Training \\ Lancaster University \\ a.darby@lancaster.ac.uk \\ Oliver Bates \\ School of Computing and \\ Communications \\ Lancaster University \\ o.bates@lancaster.ac.uk \\ Manu J. Brueggemann \\ HighWire Centre for Doctoral \\ Training \\ Lancaster University \\ m.brueggemann@lancaster.ac.uk \\ Benjamin Wohl \\ HighWire Centre for Doctoral \\ Training \\ Lancaster University \\ b.wohl@lancaster.ac.uk \\ Lindsay MacDonald Vermeulen \\ Department of Computer \\ Science \\ Aarhus University \\ lindsay.vermeulen@alexandra.dk \\ David Feldman \\ Trisula Solutions Inc. \\ david@trisula.ca \\ Permission to make digital or hard copies of all or part of this work for personal or \\ classroom use is granted without fee provided that copies are not made or distributed \\ for profit or commercial advantage and that copies bear this notice and the full citation \\ on the first page. Copyrights for components of this work owned by others than ACM \\ must be honored. Abstracting with credit is permitted. To copy otherwise, or republish, \\ to post on servers or to redistribute to lists, requires prior specific permission and/or a \\ fee. Request permissions from permissions@acm.org. \\ ACM. \\ CHI'18 Extended Abstracts, April 21-26, 2018, Montreal, QC, Canada \\ ACM 978-1-4503-5621-3/18/04. \\ https://doi.org/10.1145/3170427.3188394
}

\begin{abstract}
$\mathrm{CHI}$ can be a multisensory overload. Attendees endure days of workshops, presentations, evening parties, and ephemeral interactions. This paper attempts to disrupt that onslaught of activities [9]. It draws inspiration from theories and methods already in $\mathrm{HCl}-$ e.g. mindfulness [1], reflective design [8], and slow design [4, 7] — to bring eight pages of silence to the conference. This is meant to disrupt CHI's busy schedule and help attendees foster resilience. In pursuit of these aims, the authors will use the time and pages offered by this paper to facilitate a group silence; quiet, for just a moment, in the midst of the hurricane that is $\mathrm{CHI}$.
\end{abstract}

\section{Author Keywords}

Silence; mindfulness; slow design; meditation; reflective design; empathy; resilience; self-preservation.

\section{ACM Classification Keywords}

H.5.m [Information interfaces and presentation (e.g., $\mathrm{HCl}$ )] Miscellaneous

\section{Introduction}

Attendees will be asked to turn off their cellphones and put away their laptops. They will then be invited to position themselves in a circle-a formation inspired by restorative justice circles [5]. Vanessa will then lead a period of silence, which will last for eight pages. Those pages follow. 
** A chime will sound and **

* Vanessa will slowly bring **

* Us out of silence. ${ }^{* *}$ 


\section{Acknowledgements}

We thank the participants and reviewers for engaging with this paper, its activity, and its authors in a form of collective, reflective solidarity. Acknowledging the importance of selfpreservation can help us establish sustainable research practises in $\mathrm{HCl}$ and beyond [3].

We furthermore wish to acknowledge two former teachers for many of the authors: Stuart Walker and Gordon Brown. Their courage to openly admit and discuss the validity of self-preservation in research, and for inviting students to join them in their investigations of quiet design [10], have informed many of our subsequent practises (e.g. [2]).

The title of this workshop quotes a line from Lin-Manuel Miranda's musical Hamilton [6], an album that faithfully accompanied several of us during many (much needed) evenings of peer support in the past two years. Acknowledging him in this way seemed fitting.

\section{About the authors}

Vanessa, Manu, Ding, Andy, and Ben are or were members of Lancaster University's experimental HighWire CDT, which focused on applied digital innovation and radical design. They'd like to thank the Digital Economy programme (RCUK Grant EP/G037582/1) for supporting HighWire.

\section{REFERENCES}

1. Kirk Warren Brown and Richard M Ryan. 2003. The benefits of being present: mindfulness and its role in psychological well-being. Journal of personality and social psychology 84, 4 (2003), 822.

2. MJ Brueggemann, Angelika Strohmayer, Matthew Marshall, Nataly Birbeck, and Vanessa Thomas. 2017. Reflexive Practices for the Future of Design Education: An Exercise in Ethno-Empathy. The Design Journal 20, 1 (2017), 1260-1269.
3. Corinne Gale, Thomas Schröder, and Paul Gilbert. 2017. Do You Practice What You Preach? A Qualitative Exploration of Therapists' Personal Practice of Compassion Focused Therapy. Clinical Psychology and Psychotherapy 24, 1 (2017), 171-185.

4. Lars Hallnäs and Johan Redström. 2001. Slow Technology-Designing for Reflection. Personal Ubiquitous Comput. 5, 3 (Jan. 2001), 201-212. DOI : http://dx.doi.org/10.1007/PL00000019

5. Wanda D McCaslin. 2005. Justice as healing: Indigenous ways. Living Justice Press St. Paul, MN.

6. Lin-Manuel Miranda. 2015. Hurricane. (2015).

7. William Odom, Richard Banks, Abigail Durrant, David Kirk, and James Pierce. 2012. Slow Technology: Critical Reflection and Future Directions. In Proceedings of the Designing Interactive Systems Conference (DIS '12). ACM, New York, NY, USA, 2. DOI : http://dx.doi .org/10.1145/2317956.2318088

8. Phoebe Sengers, Kirsten Boehner, Shay David, and Joseph 'Jofish' Kaye. 2005. Reflective Design. In Proceedings of the 4th Decennial Conference on Critical Computing: Between Sense and Sensibility (CC '05). ACM, New York, NY, USA, 49-58. DOI : http://dx.doi.org/10.1145/1094562.1094569

9. Vanessa Thomas, Manu J. Brueggemann, Ding Wang, Laura S. Gaytán-Lugo, and Nicola J. Bidwell. 2018. Silent SIG: Reflection in action at CHI. In $\mathrm{CHI}$ '18 Extended Abstracts on Human Factors in Computing Systems (CHI EA '18). ACM, New York, NY, USA, 4. DOI : http://dx.doi.org/10.1145/3170427.3185362

10. Stuart Walker. 2017. Design for Life: Creating Meaning in a Distracted World. Routledge. 